\title{
Performance and carcass quality of feedlot- or pasture-finished Nellore heifers according to feeding managements in the postweaning phase ${ }^{1}$
}

\section{Daniel Rume Casagrande ${ }^{2}$, Mariana Vieira Azenha ${ }^{3}$, Bruno Ramalho Vieira ${ }^{3}$, Flávio Dutra de Resende $^{4}$, Marcelo Henrique de Faria ${ }^{4}$, Telma Teresinha Berchielli ${ }^{3}$, Ana Cláudia Ruggieri ${ }^{3}$, Ricardo Andrade Reis ${ }^{3}$}

\author{
${ }^{1}$ Research financed by FAPESP \\ 2 Departamento de Zootecnia, Universidade Federal de Lavras, Lavras, MG, Brasil. \\ ${ }^{3}$ Departamento de Zootecnia, Universidade Estadual Paulista "Julio de Mesquita Filho", Jaboticabal, SP, Brasil. \\ ${ }^{4}$ Agência Paulista de Tecnologia dos Agronegócios, Colina, SP, Brasil.
}

\begin{abstract}
The objective of this study was to evaluate the postweaning history of heifers kept on marandu grass pastures with three canopy heights, in a continuous-grazing system, during the rainy period, on feedlot- or pasture finishing. The effects of three canopy heights $(15,25$ and $35 \mathrm{~cm}$ ) associated with two supplements (mineral salt and protein-energy supplement) and two finishing systems in the dry period (feedlot and open pasture) were studied in the postweaning period during the rainy season. The adopted design was completely randomized, with seven replications (animals) in a $2 \times 2$ factorial arrangement. The animals which received protein-energy supplement reached the finishing period with greater body weight in relation to those fed mineral salt. In both feedlot and pasture finishing systems, compensatory gain effect was observed in the animals that remained on the low pastures during postweaning compared with the high pastures. This compensatory gain was not verified in the animals that received protein-energy supplement in relation to the mineral salt, and thus the animals were slaughtered beforehand. The heifers on pastures with 25 or $35 \mathrm{~cm}$ in height were slaughtered in the same period, and those kept on the low pastures were slaughtered afterwards. The studied factors in the postweaning phase did not affect the carcass characteristics. Animals finished in feedlot slaughtered with the same body weight as those finished on pasture show greater carcass yield, subcutaneous fat deposition and renal pelvic and inguinal fat and greater losses with trimmings for cleaning the main hindquarter meat cuts; however, they provide cuts with the same weight but greater fat cover.
\end{abstract}

Key Words: animal performance, animal supplementation, canopy height, intake, meat cuts

\section{Introduction}

Management techniques that allow for increased animal performance in the beef-cattle postweaning phase have been widely studied in the last few years, aiming to reduce the age at slaughter or age at first calving. Pasture management and diet supplementation for grazing animals are techniques that provide increase in animal performance (Casagrande et al.; 2011b Moretti et al., 2011) in many stages of development, including postweaning. Thus, in a productive system, knowing the effect of some management practices in one of the animal life stages on the subsequent phase is of great importance in order to determine the most profitable forms of management. The use of proteinenergy supplements in the postweaning phase increases the production costs, but it may be advantageous if it can reduce the finishing period, be it in feedlot or on pasture (Thiago \& Silva, 2001).

The choice of which pasture management to be utilized also interferes directly with the profitability of the system.
The pasture intensity to be chosen will depend mainly on the objective of the farmer as regards animal performance. In situations of higher pasture intensity, performance per area is prioritized; in low-intensity cases, the priority becomes individual performance (Casagrande et al., 2011a). This flexibility is possible because forage grasses can be managed in a wide range of grazing intensities without causing degradation of the pasture. Thus, if postweaning animals reared on lower pastures present compensatory gains at finishing and are slaughtered at the same time as those which spent their postweaning phase on higher pastures, prioritizing gain per area at postweaning becomes advantageous, given that the system productivity increases significantly.

Based on the above, the objective of the present study is to evaluate the postweaning history of Nellore heifers supplemented on marandu grass pastures with three management heights, under continuous grazing, on the finishing phase carried out in feedlot or on pasture. It was also aimed to establish relationships of these managements 
with the characteristics of carcass and meat cuts of the animals.

\section{Material and Methods}

The present study was conducted in the Forage Sector of the Department of Animal Science of FCAV/UNESP, Jaboticabal/SP, Brazil located at geographical coordinates $21^{\circ} 15^{\prime} 22^{\prime \prime}$ South latitude, $48^{\circ} 18^{\prime} 58^{\prime \prime}$ West longitude, and $595 \mathrm{~m}$ altitude. The experiment was set on a Brachiaria brizantha (Hochst ex A. Rich) Stapf cv Marandu pasture established in 2001 on a Red Latosol soil (Santos et al., 2006). According to the Köppen classification, the climate in Jaboticabal city is subtropical type Cwa, with rainy summers and dry winters (Table 1).

The experimental period was divided in two phases: postweaning period, which started on January 3, 2009, and ended on April 28, 2008, and the finishing period, starting from this date and ending when the animals reached $360 \mathrm{~kg}$ body weight. The first group of slaughtered animals was composed of 28 animals from the feedlot and two that were on pasture; this group was slaughtered on July 24, 2008. The end of the experiment occurred with the slaughter of the sixth lot, composed of 11 animals finished on pasture, performed on March 11, 2009.

In the postweaning phase, the experimental area consisted of 12 experimental paddocks of marandu grass, with an area of 0.7 to 1.3 ha each. Another five hectares were divided in paddocks as a reserve area. In this phase, the grazing system utilized was continuous grazing with

Table 1 - Rainfall and monthly means of minimum, average and maximum air temperature during the experimental period $^{1}$

\begin{tabular}{|c|c|c|c|c|c|}
\hline Month & $\begin{array}{c}\text { Rainfall } \\
\text { (mm) }\end{array}$ & $\begin{array}{c}\text { Days of } \\
\text { rain }\end{array}$ & $\begin{array}{l}\text { Minimum } \\
\text { temperature } \\
\left({ }^{\circ} \mathrm{C}\right)\end{array}$ & $\begin{array}{c}\text { Average } \\
\text { temperature } \\
\left({ }^{\circ} \mathrm{C}\right)\end{array}$ & $\begin{array}{c}\text { Maximum } \\
\text { temperature } \\
\left({ }^{\circ} \mathrm{C}\right)\end{array}$ \\
\hline Dec/2007 & 204.4 & 13 & 20.0 & 24.8 & 31.5 \\
\hline Jan/2008 & 325.0 & 22 & 20.1 & 23.5 & 29.2 \\
\hline $\mathrm{Feb} / 2008$ & 302.7 & 20 & 19.8 & 23.9 & 30.3 \\
\hline $\mathrm{Mar} / 2008$ & 108.4 & 14 & 18.8 & 23.2 & 29.6 \\
\hline Apr/2008 & 131.4 & 13 & 18.1 & 22.3 & 28.8 \\
\hline May/2008 & 73.1 & 4 & 14.2 & 19.1 & 26.1 \\
\hline Jun/2008 & 11.3 & 4 & 14.0 & 19.4 & 27.0 \\
\hline Jul/2008 & 0.0 & 0 & 12.3 & 19.1 & 28.2 \\
\hline Aug/2008 & 24.2 & 5 & 15.4 & 21.8 & 30.1 \\
\hline Sep/2008 & 15.1 & 8 & 14.9 & 21.8 & 30.2 \\
\hline Oct/2008 & 60.5 & 11 & 19.2 & 24.6 & 31.6 \\
\hline Nov/2008 & 81.8 & 14 & 18.8 & 24.3 & 32.1 \\
\hline Dec/2008 & 278.9 & 14 & 19.1 & 23.9 & 31.0 \\
\hline $\mathrm{Jan} / 2009$ & 238.0 & 18 & 19.8 & 23.8 & 29.7 \\
\hline $\mathrm{Feb} / 2009$ & 190.6 & 16 & 20.6 & 24.7 & 31.2 \\
\hline Mar/2009 & 217.9 & 16 & 20.2 & 24.4 & 31.0 \\
\hline
\end{tabular}

${ }^{1}$ Data obtained from the Exact Sciences Department of FCAV/Jaboticabal, located $800 \mathrm{~m}$ from the experimental site. variable stocking rate so as to keep the canopy with heights between 15, 25 and $35 \mathrm{~cm}$ (Casagrande et al., 2011b). Eighty-four Nellore heifers with average age of 13 months previously selected from a group of 600 animals were used, utilizing body weight and tameness as selection criteria. The initial average body weight was $214 \pm 2 \mathrm{~kg}$. After the heifers were chosen, they were identified with earrings and randomly assigned to the treatments. During the postweaning phase, the animals were subjected to six treatments in a $3 \times 2$ factorial arrangement, composed of three grazing heights $(15,25$ and $35 \mathrm{~cm})$ and two types of supplementation (mineral salt ad libitum and proteinenergy supplement), provided at $3 \mathrm{~g} / \mathrm{kg}$ body weight (BW) per day (Table 2).

During the finishing phase, the animals were divided into two treatments (finishing systems): on pasture and in feedlot. Thus, there were 12 treatments, in a $3 \times 2 \times 2$ factorial arrangement, with seven replications, totaling 84 experimental animals. Finishing on pasture was performed on 20 ha of marandu grass pasture.

The grazing method adopted was rotational stocking, in which the animals were switched among paddocks when the forage mass was lower than $2000 \mathrm{~kg} / \mathrm{ha}$. In this phase, the animals were gathered in two groups and placed in different paddocks. Each group was formed with at least three and at most four animals from each treatment, randomly defined, totaling 21 animals per group. All

Table 2 - Composition of the concentrate supplements utilized during the postweaning phase, from January to April 2008

\begin{tabular}{ll}
\hline \multirow{2}{*}{ Ingredients } & \multicolumn{2}{c}{ Supplements } \\
\cline { 2 - 3 } & Mineral salt $\quad$ Energy protein \\
\hline
\end{tabular}

$$
\text { Composition of the supplements }
$$

$\begin{array}{lcc}\text { Citrus pulp }(\mathrm{g} / \mathrm{kg}) & 0 & 370 \\ \text { Cottonseed meal-38 }(\mathrm{g} / \mathrm{kg}) & 0 & 370 \\ \text { Megalac }{ }^{\circledR}(\mathrm{g} / \mathrm{kg}) & 0 & 150 \\ \text { Urea }(\mathrm{g} / \mathrm{kg}) & 0 & 31 \\ \text { Mineral }(\mathrm{g} / \mathrm{kg}) & 1000 & 79 \\ \text { Total digestible nutrients }(\mathrm{g} / \mathrm{kg} \mathrm{DM}) & 0 & 820 \\ \text { Crude protein }(\mathrm{g} / \mathrm{kg} \text { DM) } & 0 & 260 \\ & \text { Supplement guaranteed levels } & \\ & 154 & 23 \\ \text { Calcium }(\mathrm{g} / \mathrm{kg}) & 90 & 6 \\ \text { Phosphorus }(\mathrm{g} / \mathrm{kg}) & 10 & 1 \\ \text { Magnesium }(\mathrm{g} / \mathrm{kg}) & 40 & 3 \\ \text { Sulfur }(\mathrm{g} / \mathrm{kg}) & 125 & 13 \\ \text { Sodium }(\mathrm{g} / \mathrm{kg}) & 1670 & 40 \\ \text { Copper }(\mathrm{mg} / \mathrm{kg}) & 1290 & 30 \\ \text { Manganese }(\mathrm{mg} / \mathrm{kg}) & 6200 & 148 \\ \text { Zinc }(\mathrm{mg} / \mathrm{kg}) & 124 & 3 \\ \text { Iodine }(\mathrm{mg} / \mathrm{kg}) & 100 & 2.4 \\ \text { Cobalt }(\mathrm{mg} / \mathrm{kg}) & 32 & 0.8 \\ \text { Selenium }(\mathrm{mg} / \mathrm{kg}) & 0 & 80 \\ \text { Monensin }(\mathrm{mg} / \mathrm{kg}) & & \end{array}$


animals received a commercial protein-energy supplement in amounts equivalent to $5 \mathrm{~g} / \mathrm{kg} \mathrm{BW} /$ day (Table 3), in the period between $13 \mathrm{~h} 30$ and $14 \mathrm{~h} 30$. Troughs of fifty and fifteen centimeters in length were used per animal for the supply of the protein-energy supplement and mineral salt, respectively.

The forage nutritional value was estimated based on the sampling harvest, simulating the animal grazing (Goes et al., 2003). These samples were dried in a forced aircirculation oven at $55{ }^{\circ} \mathrm{C}$ for 72 hours, and subsequently ground in a Wiley mill with $1 \mathrm{~mm}$ screen sieve, before being subjected to chemical analysis. In September 2008, the intake of the pasture-finished animals was evaluated. To estimate fecal production, the marker LIPE ${ }^{\circledR}$ (isolated, purified and enriched lysine from Eucalyptus grandis) was supplied daily in capsules containing $0.5 \mathrm{~g}$ of it, during seven days, of which two were used for adaptation and five for collection. For this evaluation, five animals per treatment were used. The collections were performed at the

Table 3 - Composition of the protein-energy supplement and concentrates utilized during the finishing phase

\begin{tabular}{lcc}
\hline & \multicolumn{2}{c}{ Supplements/Concentrate } \\
\cline { 2 - 3 } Ingredients & BellPeso SV ${ }^{\circledR 1}$ & BellPeso Colina ${ }^{\circledR 2}$ \\
\hline \multicolumn{2}{c}{ Guaranteed level of the supplements } \\
Total digestible nutrients $(\mathrm{g} / \mathrm{kg} \mathrm{DM})$ & 600 & 650 \\
Crude protein $(\mathrm{g} / \mathrm{kg} \mathrm{DM})$ & 250 & 210 \\
Calcium $(\mathrm{g} / \mathrm{kg})$ & 23.0 & 18.0 \\
Phosphorus $(\mathrm{g} / \mathrm{kg})$ & 6.0 & 4.0 \\
Magnesium $(\mathrm{g} / \mathrm{kg})$ & 1.0 & 2.2 \\
Sulfur $(\mathrm{g} / \mathrm{kg})$ & 3.0 & 2.3 \\
Sodium $(\mathrm{g} / \mathrm{kg})$ & 13.0 & 2.5 \\
Copper $(\mathrm{mg} / \mathrm{kg})$ & 40.0 & 18.0 \\
Manganese $(\mathrm{mg} / \mathrm{kg})$ & 30.0 & 40.0 \\
Zinc $(\mathrm{mg} / \mathrm{kg})$ & 148.0 & 40.0 \\
Iodine $(\mathrm{mg} / \mathrm{kg})$ & 3.0 & 2.0 \\
Cobalt $(\mathrm{mg} / \mathrm{kg})$ & 2.4 & 1.0 \\
Selenium $(\mathrm{mg} / \mathrm{kg})$ & 0.8 & - \\
Monensin $(\mathrm{mg} / \mathrm{kg})$ & 80 & - \\
\hline
\end{tabular}

${ }^{1}$ Supplied to the pasture-finished animals.

${ }^{2}$ Supplied to the feedlot-finished animals. moment the capsules were supplied, by rectal collection. Approximately $15 \mathrm{~g}$ of the composite fecal samples were sent to Universidade Federal de Minas Gerais for estimation of the fecal dry matter production from two LIPE ${ }^{\circledR}$-reading methods, according to Rodríguez et al. (2006).

Intake was estimated based on the fecal production by using indigestible neutral detergent fiber (iNDF) as an indigestibility marker (Detmann et al., 2001). The indigestible neutral detergent fiber of the simulatedgrazing samples, supplements and feces was estimated by incubating the samples for 264 hours in an animal cannulated in the rumen (Casali et al., 2008). After this procedure, the samples were washed in running water, dried and the NDF was determined as previously described. The supplement intake was estimated as a function of the body weight of the animals and the amount provided daily. The forage dry matter intake was calculated with the equation proposed by Detmann et al. (2001): TDMI (kg/ day $)=\{[(\mathrm{FO} \times \mathrm{CMF})-\mathrm{MS}] / \mathrm{CMFO}\}+\mathrm{SMDI}$; in which TDMI $=$ total dry matter intake $(\mathrm{kg} /$ day $) ; \mathrm{FO}=$ fecal output $(\mathrm{kg} /$ day); $\mathrm{CMF}=$ concentration of the marker in the feces $(\mathrm{kg} / \mathrm{kg}) ; \mathrm{MS}=$ marker in present in the supplement ( $\mathrm{kg} /$ day); $\mathrm{CMFO}=$ concentration of the marker in the forage $(\mathrm{kg} / \mathrm{kg})$; and SDMI $=$ supplement DM intake $(\mathrm{kg} /$ day $)$. The total dry matter and forage intakes were also expressed as $\mathrm{g} / \mathrm{kg}$ $\mathrm{BW} /$ day, by dividing the daily intake by the average weight of the animals.

The animals were randomly distributed into forty-two $8 \mathrm{~m}^{2}$ stalls provided with individual troughs and drinkers. The diet was formulated with the same proportion of roughage and concentrate, on a dry matter basis. The roughage utilized was a silage of the hybrid corn Maximus from Syngenta (Table 4), stored in stack silos. A commercial concentrate was used to produce the diet (Table 3 ).

The diets were supplied daily, at $07 \mathrm{~h} 00$ and the leftovers were collected and weighed daily before a new supply.

Table 4 - Chemical composition of samples of corn and simulated grazing performed by Nellore heifers on marandu pasture during the finishing phase on pasture and in feedlot

\begin{tabular}{|c|c|c|c|c|c|}
\hline \multirow{2}{*}{ Variables } & \multirow{2}{*}{ Corn silage } & \multicolumn{4}{|c|}{ Simulated-grazing samples } \\
\hline & & Fall & Winter & Spring & Summer \\
\hline Mineral matter (\% DM) & 4.10 & 8.9 & 8.7 & 10.4 & 7.5 \\
\hline Organic matter (\%DM) & 95.90 & 91.1 & 91.3 & 89.6 & 92.5 \\
\hline Crude protein $(\% \mathrm{DM})$ & 9.22 & 12.2 & 10.0 & 11.1 & 13.5 \\
\hline Neutral detergent insoluble protein/Crude protein $(\% \mathrm{CP})$ & 11.50 & 37.2 & 36.9 & 41.2 & 48.5 \\
\hline Acid detergent insoluble protein/Crude protein $(\% \mathrm{CP})$ & 5.31 & 8.2 & 5.3 & 13.0 & 8.8 \\
\hline Neutral detergent fiber* (\%DM) & 43.51 & 62.6 & 61.3 & 58.9 & 62.4 \\
\hline Acid detergent fiber $(\% \mathrm{DM})$ & 22.06 & 36.6 & 35.8 & 33.8 & 33.0 \\
\hline Lignin $(\% \mathrm{DM})$ & 2.38 & 6.1 & 6.8 & 4.6 & 3.6 \\
\hline Non-fibrous carbohydrates (\%DM) & 39.33 & 14.6 & 18.4 & 18.3 & 15.5 \\
\hline Ether extract $(\% \mathrm{DM})$ & 3.83 & 1.6 & 1.6 & 1.3 & 1.1 \\
\hline
\end{tabular}


The amount provided was calculated daily, based on the refusals from the previous day, for each animal, so that they would represent 5 to $10 \%$ of the total supplied. Dry matter intake was measured daily as the difference between the feed supplied and the leftovers in each stall. The refusals and total feed offered to each animal were weighed weekly, forming a composite sample at the end of the experimental period. These samples were dried in an oven at $55^{\circ} \mathrm{C}$ for 72 hours, and subsequently ground in a Wiley mill with a $1 \mathrm{~mm}$ screen sieve to determine the dry matter content of the sample.

In both the samples obtained with grazing animals and those from silage, the crude protein content was evaluated according to the procedures described in the AOAC (1990), by Dumas' combustion method, utilizing an automated protein analyzer (Leco 528LC). In the evaluation of the neutral detergent fiber, TNT (nonwoven textile; $100 \mathrm{mg} / \mathrm{m}^{2}$ ) bags were used, as proposed by Casali et al. (2009). The organic matter, ether extract and acid detergent fiber contents were determined by the methodology described by Silva \& Queiroz (2002). The non-fibrous carbohydrates were estimated by the total subtraction of organic matter $(100 \%)$ from the neutral detergent fiber, crude protein and ether-extract contents (Silva \& Queiroz 2002). The cellulose was solubilized by using sulfuric acid $72 \%$, obtaining the lignin as the difference in relation to the acid detergent fiber (ADF) (Robertson \& Van Soest, 1985).

In the postweaning phase, the animals were weighed monthly so that the last weighing was the first of the finishing period. In this occasion, the loin-eye area (LEA) and the dorsal subcutaneous fat thickness (SFT) of all animals were evaluated. For this procedure, ultrasound device PIEMEDICAL AQUILA ${ }^{\circledR}$ and a 3.5 MHZ linear probe were utilized. The LEA and SFT characteristics were measured between the 12th and 13th ribs transversally over the longissimus lumborum muscle. From this moment, the animals were weighed every 28 days, always after being deprived of liquids and solids for 12 hours. When an animal, regardless of the finishing system, reached over $360 \mathrm{~kg}$ body weight, it was slaughtered in a commercial slaughterhouse, located at $90 \mathrm{~km}$ from the experimental site. The finishing period was calculated based on the first weighing of the finishing period until the slaughter date of each animal.

On the day before slaughter, the animals were weighed having been deprived of solids and liquids for 12 hours. The performance in the finishing phase was measured by utilizing the weight difference between the first weighing and the pre-slaughter weighing. After slaughter, the carcasses were identified by the order of slaughter, sawn, and the pelvic, renal and inguinal fat was removed. Next, the half-carcasses were weighed, determining the hot carcass weight and carcass yield. Subsequently, they were placed in a cold chamber, where they remained for 24 hours at least. After the cooling period was over, the half-carcasses were weighed, thereby determining the cold carcass weight, cooling loss and commercial carcass dressing (ratio between cold carcass weight and slaughter weight). In the sequence, the carcass depth and the internal half-carcass length were measured. The carcass length was determined as the distance between the cranial end of the iliac crest and the cranial border of the first rib. In this occasion, $\mathrm{pH}$ and temperature of the half-carcasses were also measured on the longissimus lumborum muscle. Afterwards, the muscle was transversely sectioned between the 12th and the 13th ribs, where the loin-eye area (LEA) was measured with a $1 \mathrm{~cm}^{2}$ reticulated grid and subcutaneous fat thickness in millimeters. In the right half-carcass, the primal cuts hindquarter, forequarter and thin flank were separated, thereby estimating the proportions of each cut.

In the hindquarter, collected from the right half-carcass, the main meat cuts sirloin, rib eye, rump heart, rump cap and tenderloin were separated. These were weighed right after boning, and named rough cuts. Next, the commercial cuts were separated, and the trimmings were removed by commercial-slaughterhouse-trained professionals, aiming at the internal market; these cuts were evaluated according to the specification of each cut. Subsequently, the trimmedcuts yield was determined in relation to the untrimmed cuts, to cold carcass weight and to hindquarter weight. The sirloin was cut at the 11th rib, and the intercostals, the excess trimmings from the lower part of the cut and also the lateral nerve were removed. The rib eye, also called round tip steak, sandwich steak and ball tip steak, corresponded to the first five ribs of the sirloin, from the 6th to 10th ribs. To obtain the rump heart, the rough cut was cut and the excess trimmings were removed. To obtain the rump cap, the lateral nerve and the trimmings from the lower part of the rough cut were removed with the aid of a beef skinner. The tenderloin utilized was chainless, i.e., the chain and the excess trimmings from the lower part of the rough cut were removed.

After weighing, the rump cap, rump heart and sirloin cuts were evaluated at pre-defined points as regards fat cover, in their subcutaneous fat thickness, using a caliper rule, expressed as $\mathrm{mm}$. The rump heart was evaluated at the central point of its fat thickness. The rump cap at the tip of the cut was named P8 and the sirloin was determined by the measurement of three points: the first at the junction 
between the end of rib eye and the beginning of the sirloin, in the central portion of the longissimus dorsi muscle, at the eleventh rib; the second point at the first lumbar vertebra, in the ventral portion of the muscle; and the third in the final portion of the cut, central part, along with the rump heart.

The animal performance in the finishing phase was evaluated within each system using a completely randomized design in a $3 \times 2$ factorial arrangement, with seven replications, corresponding to the history of each animal (canopy height $\times$ type of supplement). For the variance analysis, procedure PROC GLM of the SAS (Statistical Analysis System, version 9.0) software was used. Means were compared by the Tukey test at $5 \%$ probability.

The data relating to carcass and meat cuts of the experimental animals were evaluated in a completely randomized design with seven replications, in a $3 \times 2 \times 2$ factorial arrangement, corresponding to the history of ach animal (canopy height $\times$ type of supplement) and the finishing systems (on pasture and in feedlot). The variance analysis was performed with the aid of SAS (Statistical Analysis System, version 9.0), with procedure PROC GLM. The means were compared by the Tukey test at $5 \%$ of probability. In all variables, the normality and homoscedasticity of the data were tested at $5 \%$ of probability.

\section{Results and Discussion}

During the postweaning phase, the animals that received protein-energy supplement had greater weight gain than those fed mineral salt (Tables 5 and 6), as did those kept on pastures with canopy heights of 25 and $35 \mathrm{~cm}$ in relation to those kept on the $15 \mathrm{~cm}$ tall grasses. The greater weight gains reflected in increase in the carcass characteristics, especially loin-eye area and dorsal subcutaneous fat, measured by ultrasound, at the end of the first experimental phase (Tables 5 and 6). Thus, at the end of the postweaning phase, the animals of greater weight gain showed greater body weight (Tables 5 and 6 ).

The confined animals which received protein-energy supplement in the postweaning phase presented, at the end of this phase, $19 \mathrm{~kg}$ higher body weight than those fed mineral salt (Table 5). However, this study factor did not affect $(P=0.259)$ the average weight gain of the animals during the feedlot-finishing phase. As a consequence, the animals fed protein-energy supplement at postweaning and which were heavier at the beginning of the finishing period took 16 less days to reach slaughter weight. The absence of compensatory gain due to the type of supplement utilized allows us to infer that the additional gain obtained by the

Table 5 - Performance of Nellore heifers reared on marandu grass pastures with different canopy heights and supplemented with mineral salt or protein-energy supplement and finished in feedlot

\begin{tabular}{|c|c|c|c|c|c|c|c|c|}
\hline \multirow{2}{*}{ Variables } & \multicolumn{4}{|c|}{ Canopy height (cm) } & \multicolumn{3}{|c|}{ Supplement } & \multirow{2}{*}{ CV $(\%)$} \\
\hline & 15 & 25 & 35 & P-value & Mineral salt & Protein-energy supplement & P-value & \\
\hline Postweaning weight gain (g/day) & $448 b$ & $552 \mathrm{ab}$ & $656 a$ & 0.022 & 460 & 643 & 0.002 & 15.3 \\
\hline Postweaning final body weight (kg) & $270 b$ & $282 \mathrm{ab}$ & 291a & 0.001 & 272 & 291 & 0.008 & 7.3 \\
\hline Postweaning final LEA $\left(\mathrm{cm}^{2}\right)$ & $45.4 \mathrm{a}$ & $52.1 \mathrm{a}$ & $52.6 \mathrm{a}$ & 0.001 & 48.6 & 51.5 & 0.025 & 8.2 \\
\hline Subcutaneous fat thickness (mm) & $2.36 \mathrm{~b}$ & $3.12 \mathrm{a}$ & $3.26 \mathrm{a}$ & 0.002 & 2.80 & 3.02 & 0.208 & 20.0 \\
\hline Weight gain at finishing (g/day) & $999 a$ & $967 \mathrm{ab}$ & $854 b$ & 0.015 & 951 & 922 & 0.259 & 13.2 \\
\hline Finishing period (days) & $101 \mathrm{a}$ & $91 \mathrm{ab}$ & $89 b$ & 0.045 & 102 & 86 & 0.038 & 24.6 \\
\hline Dry matter intake (kg/day) & 7.7 & 7.9 & 7.4 & 0.291 & 7.6 & 7.7 & 0.409 & 13.5 \\
\hline Dry matter intake (g/kg BW/day) & 24.1 & 23.8 & 22.4 & 0.248 & 23.7 & 23.0 & 0.463 & 12.0 \\
\hline Conversion (kg DM/kg gain) & $7.7 b$ & $8.1 \mathrm{ab}$ & $8.6 \mathrm{a}$ & 0.048 & 8.0 & 8.3 & 0.228 & 13.5 \\
\hline
\end{tabular}

Means followed by the same lowercase letter within each studied factor do not differ according to the Tukey test at $5 \%$ of probability.

LEA - loin-eye area.

Table 6 - Performance of Nellore heifers reared on marandu grass pastures with different canopy heights and supplemented with mineral salt or protein-energy supplement and finished on pasture

\begin{tabular}{|c|c|c|c|c|c|c|c|c|}
\hline \multirow{2}{*}{ Variables } & \multicolumn{4}{|c|}{ Canopy height (cm) } & \multicolumn{3}{|c|}{ Supplement } & \multirow{2}{*}{$\mathrm{CV}(\%)$} \\
\hline & 15 & 25 & 35 & P-value & Mineral salt & Protein-energy supplement & P-value & \\
\hline Weight gain in the postweaning phase (g/day) & $406 \mathrm{~b}$ & $559 \mathrm{ab}$ & $682 \mathrm{a}$ & 0.035 & 460 & 638 & 0.004 & 16.1 \\
\hline Postweaning final body weight $(\mathrm{kg})$ & $261 b$ & $287 \mathrm{a}$ & $289 \mathrm{a}$ & 0.002 & 270 & 289 & 0.007 & 8.7 \\
\hline Postweaning final LEA $\left(\mathrm{cm}^{2}\right)$ & $46.5 b$ & $52.2 \mathrm{a}$ & $53.3 \mathrm{a}$ & 0.002 & 48.8 & 52.6 & 0.018 & 9.7 \\
\hline Subcutaneous fat thickness (mm) & $2.22 b$ & $3.10 \mathrm{a}$ & $3.08 \mathrm{a}$ & 0.009 & 2.70 & 2.90 & 0.314 & 22.6 \\
\hline Weight gain in the finishing phase (g/day) & $406 \mathrm{a}$ & $342 b$ & $341 b$ & 0.041 & 375 & 350 & 0.072 & 13.2 \\
\hline Finishing period (days) & $271 \mathrm{a}$ & $225 b$ & $234 b$ & 0.038 & 256 & 231 & 0.025 & 28.4 \\
\hline Dry matter intake (kg/day) & 7.5 & 7.5 & 7.4 & 0.587 & 7.5 & 7.4 & 0.854 & 6.9 \\
\hline Forage intake (kg/day) & 6.0 & 6.0 & 5.8 & 0.614 & 6.0 & 5.9 & 0.785 & 7.7 \\
\hline Dry matter intake (g/kg BW/day) & 25 & 24 & 23 & 0.513 & 24 & 24 & 0.982 & 5.3 \\
\hline Forage intake (g/kg BW/day) & 20 & 19 & 18 & 0.487 & 19 & 19 & 0.976 & 6.6 \\
\hline
\end{tabular}

Means followed by the same lowercase letter within each studied factor do not differ according to the Tukey test at $5 \%$ of probability.

LEA - loin-eye area. 
animals that consumed the protein-energy supplement during postweaning remains until their slaughter. Thus, it is clear that supplementing growing grazing animals is a technique that helps reduce their slaughter age.

The animals kept on the $35 \mathrm{~cm}$ tall pastures were heavier by $21 \mathrm{~kg}$ at the end of postweaning than those on the $15 \mathrm{~cm}$ pastures, and neither of them differed $(\mathrm{P}>0.05)$ from those kept on pastures with $24 \mathrm{~cm}$ in height (Table 5). Under such conditions, the compensatory gains observed in the finishing phase for the animals that were kept on the lower pastures during the postweaning phase were higher than those on the $35 \mathrm{~cm}$ pastures by $145 \mathrm{~g} /$ day; neither of them differed from the heifers post-weaned on pastures of medium height. However, even with this additional gain, the animals on the tall pastures were slaughtered on average 12 and 2 days before the animals that were on the low and medium-height pastures, respectively.

The isolated evaluation of individual performance may lead to a misleading conclusion, because on the lower pastures, the stocking rate was higher (Casagrande et al., 2011b). Thus, during the postweaning phase, the stocking rates were 4.8 and 2.0 animals/ha lower in the $35 \mathrm{~cm}$ tall pastures in relation to the 15 and $25 \mathrm{~cm}$ pastures, respectively. Therefore, comparison between the systems must take their productivity into account. When managing pastures with a height range close to $25 \mathrm{~cm}$ during postweaning and subsequently finishing animals in feedlot, in similar confinement periods, one would have $33 \%$ more animals in relation to the use of the same system with pastures in height ranges close to 35 in postweaning. The same reasoning is valid for the low pastures at postweaning, in which $70 \%$ more animals would be slaughtered in relation to the maintenance of tall pastures. However, they would take 12 more days in feedlot for slaughter. Following the same reasoning regarding the use of protein-energy supplement at postweaning, in this circumstance, the feedlot period was shorter and the stocking rate was higher in this phase, which would allow for $9 \%$ more slaughtered animals in a shorter period of time.

The production system with shortest finishing period, 83 days, was obtained when the heifers were kept on pasture with an average height of $25 \mathrm{~cm}$, receiving protein-energy supplement during the postweaning phase and finished in feedlot. In confinement, the system in which heifers took longest to be finished (116 days) was when the animals were reared receiving mineral salt and kept on pastures with $15 \mathrm{~cm}$ of height.

Dry matter intake in the feedlot did not vary with any of the studied factors ( $\mathrm{P}>0.05$ ), averaging $7.65 \mathrm{~kg} /$ day or $23.4 \mathrm{~g} / \mathrm{kg}$ of BW/day. Likewise, nutrient intake in confinement did not vary according to any studied factor $(\mathrm{P}>0.05)$. Thus, feed conversion was more efficient in the animals that were kept on pastures with canopies close to $15 \mathrm{~cm}$ in height and did not vary according to the type of supplementation used in the postweaning phase.

Similarly to what was observed with the heifers finished in feedlot, the weight of those finished on pasture, at the end of the postweaning period, was higher in those fed protein-energy supplement than mineral salt, and also in the animals that were kept on tall pastures in relation to those on low pastures, and neither differed from those on $25 \mathrm{~cm}$ tall pastures (Table 6). Although the magnitudes are different, the performance trends of animals finished in feedlot and on pasture were different.

Compensatory gains were observed during the pasturefinishing of the animals reared on $15 \mathrm{~cm}$ tall pastures, compared with the others. However, even so, the finishing time for these animals was, on average, 46 and 37 days longer in relation to the animals kept on 15 and $25 \mathrm{~cm}$ tall pastures, respectively. The use of supplements in the postweaning phase did not interfere $(\mathrm{P}>0.05)$ with weight gain during the finishing phase on pasture. Thus, the animals that received protein-energy supplement in the postweaning phase reached slaughter weight before those supplemented with mineral salt, because they had lower performance in the postweaning phase and reached the finishing phase with lower body weight (Table 6).

The results of the present study are in agreement with those observed in the literature (Bail et al., 2000; Costa et al., 2007), in which, after having their intake moderately restricted, the animals showed greater weight gain in the subsequent period, feeding ad libitum, in relation to the animals that never went through feeding restrictions. In the postweaning phase, the animals that remained on $15 \mathrm{~cm}$ pastures underwent restricted dry matter intake in relation to the others, which was caused by non-nutritional factors related to the canopy structure (Casagrande, 2010). The restriction in the intake of the animals that spent their postweaning period on the lower pastures was approximately $18 \%$ relative to those kept on pastures taller than $25 \mathrm{~cm}$. During the postweaning phase, compared with the mineral salt, the protein-energy supplement increased total dry matter intake (forage plus supplement intake). However, the forage dry matter intake did not vary with the use of different supplements (Casagrande, 2010). This fact may explain the similarities in the performance of the animals during finishing. In a study with uncastrated steers subjected to different feeding regimens during the postweaning and fattening phases, Resende et al. (2008), verified increase in performance with the use of protein-energy supplements 
in the postweaning phase during the rainy period, and the authors also did not observe compensatory gains in the finishing of these animals caused by this factor.

Although the feedlot- and pasture-finishing systems were analyzed in different experiments, it is evident that the use of feedlot within the production system can be an interesting alternative not only from the economic, but especially from the productive standpoint, with the clearing of the pasture area for other animals and reduction in slaughter age. When the postweaning and finishing phases were carried out on pasture, the animals that entered the production system in January 2008 were mostly slaughtered in February or March of the following year, whereas the last animals slaughtered in confinement were slaughtered in September 2008. Thus, adopting this postweaning and finishing system with heifers, utilizing only pasture, it would not be possible to end a productive cycle in one year. This fact may compromise the beginning of the fattening process in animals in the following year, indicating the importance of strategic use of feedlot on a farm.

Regardless of the finishing system and of the studied factors during the postweaning phase, the slaughter weight was the same $(\mathrm{P}>0.05)$. No study factor in postweaning interfered $(\mathrm{P}>0.05)$ with the carcass variables studied (Tables 7, 8, 9, 10 and 11). The feeding systems studied in the postweaning phase promoted differences in weight gain, reflecting in reduction of the finishing period in the system in which the animals had better performance. However, within each finishing system, all animals were slaughtered under similar conditions, i.e., with the same dietary energy levels, slaughter weights and similar ages, with two months of difference at most, according to the postweaning study factors.

The finishing system affected some of the carcass characteristics. Carcass yield was greater in the feedlotfinished animals $(\mathrm{P}<0.05)$ compared with those on pasture (Table 7). This higher carcass yield is related to the diet provided, which, in the feedlot, was composed of equal parts of forage (corn silage) and concentrate, whereas the diet for the grazing animals was mostly forage, with greater fiber content. Bürger et al. (2000) verified quadratic effect of the retention time of the digesta, in which lower values were observed when diets with approximately $60 \%$ of concentrate were used. Based on these reports, animals with higher passage rate are expected to excrete more during the same fasting period. Thus, the gastrointestinal tract of the animals finished in feedlot, at the pre-slaughter weighing, was shorter in relation to those on pasture, such that the percentage of carcass in relation to the slaughter weight was higher in the confined animals. Another explanation for the greater carcass yield of the feedlot-finished animals may be related to the carcass compactness index, which was greater in the animals finished in feedlot (Table 9). In addition, the carcass had greater fat cover, as a result of diets with higher energy density of these animals, represented by a greater accumulation of fat tissue in the carcasses (Tables 8 and 11). Therefore, because of this better fat cover, these animals had greater carcass yield.

Table 7 - Carcass characteristics of Nellore heifers reared on marandu grass pasture with different canopy heights and supplemented with mineral salt or protein-energy supplement finished in feedlot or on pasture

\begin{tabular}{|c|c|c|c|c|c|c|c|c|c|c|c|}
\hline \multirow[b]{2}{*}{ Variable } & \multicolumn{4}{|c|}{ Canopy height $(\mathrm{cm})$} & \multicolumn{3}{|c|}{ Supplement } & \multicolumn{3}{|c|}{ Finishing } & \multirow[b]{2}{*}{$\mathrm{CV}(\%)$} \\
\hline & 15 & 25 & 35 & P-value & Mineral salt & $\begin{array}{c}\text { Protein-energy } \\
\text { supplement }\end{array}$ & P-value & Feedlot & Pasture & P-value & \\
\hline Slaughter weight (kg) & 370 & 365 & 363 & 0.247 & 366 & 365 & 0.844 & 366 & 365 & 0.934 & 3.8 \\
\hline Hot carcass weight (kg) & 198 & 195 & 196 & 0.581 & 194 & 198 & 0.117 & 199 & 193 & 0.082 & 4.7 \\
\hline Carcass yield $(\mathrm{g} / \mathrm{kg})$ & 535 & 533 & 541 & 0.194 & 531 & 541 & 0.065 & 544 & 529 & 0.044 & 2.8 \\
\hline Cold carcass weight $(\mathrm{kg})$ & 196 & 193 & 194 & 0.602 & 193 & 196 & 0.111 & 198 & 191 & 0.073 & 4.7 \\
\hline Cooling loss $(\mathrm{g} / \mathrm{kg})$ & 10.6 & 7.7 & 10.2 & 0.112 & 9.8 & 9.1 & 0.710 & 8.0 & 10.9 & 0.070 & 28.2 \\
\hline Commercial carcass yield (g/kg) & 530 & 529 & 535 & 0.308 & 526 & 537 & 0.063 & 540 & 523 & 0.022 & 2.8 \\
\hline
\end{tabular}

Table 8 - Carcass characteristics of Nellore heifers reared on marandu grass pasture with different canopy heights and supplemented with mineral salt or protein-energy supplement finished in feedlot or on pasture

\begin{tabular}{|c|c|c|c|c|c|c|c|c|c|c|c|}
\hline \multirow[b]{2}{*}{ Variable } & \multicolumn{4}{|c|}{ Canopy height $(\mathrm{cm})$} & \multicolumn{3}{|c|}{ Supplement } & \multicolumn{3}{|c|}{ Finishing } & \multirow[b]{2}{*}{$\mathrm{CV}(\%)$} \\
\hline & 15 & 25 & 35 & P-value & Mineral salt & $\begin{array}{c}\text { Protein-energy } \\
\text { supplement }\end{array}$ & P-value & Feedlot & Pasture & P-value & \\
\hline $\operatorname{LEA}\left(\mathrm{cm}^{2}\right)$ & 58.4 & 60.5 & 61.2 & 0.310 & 59.0 & 61.1 & 0.165 & 59.0 & 61.1 & 0.503 & 10.5 \\
\hline $\operatorname{rLEA}\left(\mathrm{cm}^{2} / 100 \mathrm{~kg}\right)$ & 29.5 & 31.0 & 31.3 & 0.162 & 30.4 & 30.8 & 0.602 & 29.5 & 31.7 & 0.179 & 10.6 \\
\hline $\mathrm{SFT}(\mathrm{mm})$ & 4.59 & 5.10 & 5.31 & 0.333 & 5.10 & 4.90 & 0.638 & 6.05 & 3.95 & 0.013 & 34.0 \\
\hline RPIF (kg) & 3.95 & 3.87 & 4.12 & 0.722 & 4.04 & 3.92 & 0.656 & 4.90 & 3.05 & 0.002 & 27.4 \\
\hline RPIF/C (g/kg) & 19.8 & 19.8 & 21.0 & 0.668 & 20.6 & 19.8 & 0.520 & 24.6 & 15.8 & 0.002 & 26.4 \\
\hline
\end{tabular}

LEA - loin-eye area; rLEA - relative loin-eye area (LEA/100 kg carcass); SFT - dorsal subcutaneous fat thickness; RPIF - renal, pelvic and inguinal fat; RPIF/C - renal, pelvic and inguinal fat per $\mathrm{kg}$ of carcass. 
The carcasses of the confined animals were $5.8 \mathrm{~kg}$ heavier than those of pasture-finished animals. However, this difference was not significant $(P=0.082)$, and, in the same manner, cold carcass weight was $6.3 \mathrm{~kg}$ higher in the confined animals compared with the others. The carcass commercial yield, i.e., the cold carcass weight in relation to the body weight at the moment of slaughter, was $17 \mathrm{~g} / \mathrm{kg}$ higher in the confined animals $(\mathrm{P}=0.22)$. The cooling losses were $36.2 \%$ greater in the carcasses of the pasturefinished animals than in those of the confined heifers, but not significant $(P=0.07)$. This indicates a trend towards lower cooling losses in carcasses with greater fat cover due to the greater accumulation of fat tissue, which protects the carcass from the harmful effects of cooling (Felício, 1997; Roça, 2001).

The loin-eye area and the relative loin-eye area did not vary with the studied factors $(\mathrm{P}>0.05)$, indicating that the muscularity of the carcasses were similar, regardless of the post-weaning method and finishing system (Table 8). The mean values observed for loin-eye area and relative loin-eye area were $60.0 \mathrm{~cm}^{2}$ and $30.6 \mathrm{~cm}^{2} / 100 \mathrm{~kg}$ carcass. Siqueira (2009) observed loin-eye area and relative loineye area of $59.9 \mathrm{~cm}^{2}$ and $34.2 \mathrm{~cm}^{2} / 100 \mathrm{~kg}$ in Brangus heifers slaughtered at an average carcass weight of $170 \mathrm{~kg}$. The loin-eye area values observed in the present study were similar to those verified by Siqueira (2009), but the relative loin-eye area was lower in the present study. This difference stems from the difference in the genetic group of the animals between the studies, because relative loineye area is directly related to the carcass muscularity, and animals of European-origin breeds have greater muscularity in relation to the zebu breeds.

The subcutaneous fat thickness in the dorsal region was higher $(\mathrm{P}=0.013)$ in the confined animals $(6.05 \mathrm{~mm})$ in comparison with those finished on pasture $(3.95 \mathrm{~mm})$. The average subcutaneous fat thickness of the animals of all treatments was above three millimeters, which is the minimum required by slaughterhouses to protect the carcass against cooling losses.

The greater subcutaneous fat deposition in the carcass of the animals finished in feedlot justifies the classification observed in the carcasses. The frequency of distribution of the carcasses of confined animals into scanty, average, standard and excessive was $0.0,17.5,80.0$ and $2.5 \%$, respectively, whereas $14.6,70.8,14.6$ and $0.0 \%$ of the animals kept on pasture had their carcasses classified as scanty, average, standard and excessive, respectively.

The renal, pelvic and inguinal fat deposition, both in absolute and relative values, was greater in the confined animals than grazing animals $(\mathrm{P}=0.002)$. The absolute values of renal, pelvic and inguinal fat were $60 \%$ higher in the confined animals (Table 8). Renal, pelvic and inguinal fat is the first site where fat is deposited, followed by intermuscular, subcutaneous and intramuscular deposition (Pethick et al., 2004). Ribeiro et al. (2002) observed higher amounts of renal, pelvic and inguinal fat when they utilized diets with greater energy concentration. This fact corroborates the data obtained in the present study, in which the diet of confined animals had greater energy content than the diet of grazing animals. With this, the deposition of fat, both renal-pelvic-inguinal and subcutaneous, was greater in the confined animals. The studied factors in the postweaning phase did not affect the deposition of fat $(\mathrm{P}>0.05)$, which was expected, because the postweaning animals were in the growth phase, prioritizing muscle deposition with low fat deposition.

The carcass $\mathrm{pH}$, measured on the longissimus lumborum, did not vary with any studied factor $(\mathrm{P}>0.05)$. The mean values were below 5.8. which is the maximum value required for exporting meat (Table 9). The temperature of the carcass, measured on the longissimus lumborum, was also not affected by the studied treatments. The carcasses of confined animals with greater fat cover were expected to cool more slowly, and consequently show lower $\mathrm{pH}$; however, this effect was not verified. One of the factors that might have played a part in this was the use of successive slaughters, in consecutive months. Slaughter on different days has a great impact on $\mathrm{pH}$, because the latter is dependent upon the stress level of the animals prior to slaughter, and stressed animals during the pre-slaughter management may have their glycogen reserves depleted. Therefore, there would be no production of lactic acid, and consequently the carcass $\mathrm{pH}$ would be high after 24 hours (Felício, 1997).

The carcass depth and length did not vary according to the studied factors $(\mathrm{P}>0.05)$. However, the carcass compactness index (carcass weight/length) was higher in confined animals $(\mathrm{P}<0.05)$, which can be explained by their greater fat cover, providing more compact carcasses (Table 9). The proportions of hindquarter, forequarter and thin flank were not changed by any studied factor $(\mathrm{P}>0.05)$. The observed means were 511, 378 and $111 \mathrm{~g} / \mathrm{kg}$ for hindquarter, forequarter and thin flank, respectively, based on the cold carcass weight. In studies with the carcass of Santa Gertrudes heifers with $202 \mathrm{~kg}$, Coutinho Filho et al. (2006) verified proportions of 500, 357 and $143 \mathrm{~g} / \mathrm{kg}$ hindquarter, forequarter and thin flank, respectively.

The gross weight of the main meat cuts hindquarter, rib eye, tenderloin, rump heart and rump cap in relation to the hindquarter weight was higher in the confined animals 
$(\mathrm{P}=0.050)$. However, the yield, i.e., the weight of the clean cut in relation to its gross weight, was higher in the animals kept on pastures in the finishing period $(\mathrm{P}=0.005)$, because the animals slaughtered on pasture showed lower fat cover, represented by lower subcutaneous fat thicknesses (Table 7), which reflects in lower carcass yields (Table 8) and lower compactness indices (Table 9), which results in reduced amount of trimmings. The weight of the trimmed cuts was similar irrespective of the studied factor $(\mathrm{P}>0.05)$, even though there was variation in the weight of the rough cuts, which was due to the greater weight of the trimmings in the cuts with higher gross weight (Table 10).

Just as for the sum of the main meat cuts of the hindquarter, the studied factors had no effect on weight and yield of the hindquarter cuts individually $(\mathrm{P}>0.05)$. Although the carcass composition as regards the proportions of muscle, bone and fat was not assessed, the analyzed variables allowed for inferring that the confined animals had greater fat deposition, which can be verified in subcutaneous fat thickness and renal, pelvic and inguinal fat.

Due to the larger quantities of fat in the carcasses of animals finished in feedlot, the quantities of trimmings removed at the cleaning of each cut were higher in the confined animals, and this explains the observed yields of the cuts. However, the weights of the clean meat cuts were similar according to the studied factors, which is because the gross weights of the same cuts were higher in confined animals.

Table 9 - Carcass characteristics of Nellore heifers reared on marandu grass pasture with different canopy heights and supplemented with mineral salt or protein-energy supplement finished in feedlot or on pasture

\begin{tabular}{|c|c|c|c|c|c|c|c|c|c|c|c|}
\hline \multirow[b]{2}{*}{ Variable } & \multicolumn{4}{|c|}{ Canopy height $(\mathrm{cm})$} & \multicolumn{3}{|c|}{ Supplement } & \multicolumn{3}{|c|}{ Finishing } & \multirow[b]{2}{*}{$\mathrm{CV}(\%)$} \\
\hline & 15 & 25 & 35 & P-value & Mineral salt & $\begin{array}{c}\text { Protein-energy } \\
\text { supplement }\end{array}$ & P-value & Feedlot & Pasture & P-value & \\
\hline $\mathrm{pH}$ & 5.73 & 5.74 & 5.78 & 0.488 & 5.75 & 5.74 & 0.714 & 5.72 & 5.79 & 0.232 & 1.8 \\
\hline Temperature $\left({ }^{\circ} \mathrm{C}\right)$ & 5.09 & 5.13 & 5.26 & 0.523 & 4.97 & 5.35 & 0.054 & 5.28 & 5.04 & 0.386 & 10.7 \\
\hline Depth $(\mathrm{cm})$ & 33.7 & 33.5 & 33.8 & 0.760 & 33.7 & 33.7 & 0.987 & 33.5 & 33.9 & 0.604 & 4.3 \\
\hline Length $(\mathrm{cm})$ & 121 & 120 & 121 & 0.332 & 121 & 121 & 0.585 & 120 & 122 & 0.380 & 2.9 \\
\hline Carcass compactness index $(\mathrm{kg} / \mathrm{cm})$ & 1.62 & 1.62 & 1.60 & 0.428 & 1.60 & 1.63 & 0.083 & 1.65 & 1.57 & 0.023 & 4.4 \\
\hline
\end{tabular}

Table 10 - Primary-cuts yield of Nellore heifers reared on marandu grass pasture with different canopy heights and supplemented with mineral salt or protein-energy supplement finished in feedlot or on pasture

\begin{tabular}{|c|c|c|c|c|c|c|c|c|c|c|c|}
\hline \multirow[b]{2}{*}{ Variable } & \multicolumn{4}{|c|}{ Canopy height $(\mathrm{cm})$} & \multicolumn{3}{|c|}{ Supplement } & \multicolumn{3}{|c|}{ Finishing } & \multirow[b]{2}{*}{ CV $(\%)$} \\
\hline & 15 & 25 & 35 & P-value & Mineral salt & $\begin{array}{c}\text { Protein-energy } \\
\text { supplement }\end{array}$ & P-value & Feedlot & Pasture & P-value & \\
\hline Hindquarter (g/kg CC) & 511 & 508 & 512 & 0.449 & 512 & 509 & 0.276 & 508 & 513 & 0.338 & 2.0 \\
\hline Forequarter (g/kg CC) & 380 & 379 & 377 & 0.496 & 377 & 380 & 0.279 & 380 & 377 & 0.648 & 2.6 \\
\hline Thin flank (g/kg CC) & 109 & 113 & 111 & 0.289 & 111 & 111 & 0.941 & 112 & 110 & 0.432 & 6.1 \\
\hline Rough cuts (g/kg HQ) & 268 & 272 & 270 & 0.533 & 268 & 271 & 0.297 & $276 a$ & $264 b$ & 0.050 & 4.3 \\
\hline Trimmings yield $(\mathrm{g} / \mathrm{kg})$ & 779 & 772 & 774 & 0.653 & 779 & 772 & 0.194 & 759 & 791 & 0.005 & 2.9 \\
\hline Trimmings (g/kg HQ) & 208 & 210 & 209 & 0.877 & 209 & 209 & 0.908 & 209 & 209 & 0.939 & 4.4 \\
\hline
\end{tabular}

CC - cold carcass; HQ - hindquarter.

Table 11 - Weight and yields of the main meat cuts of the hindquarter of Nellore heifers reared on marandu grass pastures with different canopy heights and supplemented with mineral salt or protein-energy supplement and finished in feedlot or on pasture

\begin{tabular}{|c|c|c|c|c|c|c|c|c|c|c|c|}
\hline \multirow[b]{2}{*}{ Variable } & \multicolumn{4}{|c|}{ Canopy height (cm) } & \multicolumn{3}{|c|}{ Supplement } & \multicolumn{3}{|c|}{ Finishing } & \multirow[b]{2}{*}{$\mathrm{CV}(\%)$} \\
\hline & 15 & 25 & 35 & P-value & Mineral salt & $\begin{array}{c}\text { Protein-energy } \\
\text { supplement }\end{array}$ & P-value & Feedlot & Pasture & P-value & \\
\hline Rib eye $(\mathrm{kg})$ & 1.45 & 1.44 & 1.44 & 0.985 & 1.39 & 1.49 & 0.053 & 1.44 & 1.44 & 0.955 & 13.3 \\
\hline Rib eye (g/kg HQ) & 28.6 & 28.8 & 28.6 & 0.977 & 27.8 & 29.5 & 0.051 & 28.2 & 29.1 & 0.629 & 12.4 \\
\hline Sirloin $(\mathrm{kg})$ & 3.68 & 3.78 & 3.70 & 0.609 & 3.70 & 3.73 & 0.704 & 3.90 & 3.53 & 0.072 & 11.0 \\
\hline Sirloin (g/kg HQ) & 73.1 & 75.9 & 73.4 & 0.307 & 74.4 & 73.9 & 0.776 & 76.6 & 71.7 & 0.156 & 9.1 \\
\hline Tenderloin $(\mathrm{kg})$ & 1.60 & 1.52 & 1.59 & 0.055 & 1.57 & 1.57 & 0.967 & 1.51 & 1.63 & 0.059 & 8.2 \\
\hline Tenderloin ( $\mathrm{g} / \mathrm{kg} \mathrm{HQ})$ & 31.5 & 30.4 & 31.7 & 0.071 & 31.5 & 30.9 & 0.183 & 29.6 & 32.9 & 0.062 & 6.5 \\
\hline Rump heart (kg) & 2.67 & 2.61 & 2.64 & 0.623 & 2.63 & 2.65 & 0.595 & 2.62 & 2.66 & 0.662 & 7.4 \\
\hline Rump heart (g/kg HQ) & 53.0 & 52.6 & 52.8 & 0.829 & 52.9 & 52.6 & 0.735 & 51.5 & 54.0 & 0.105 & 5.9 \\
\hline Rump cap (kg) & 1.13 & 1.09 & 1.12 & 0.661 & 1.10 & 1.13 & 0.428 & 1.18 & 1.05 & 0.093 & 13.4 \\
\hline Rump cap (g/kg HQ) & 21.9 & 22.0 & 22.2 & 0.930 & 22.1 & 22.0 & 0.874 & 23.1 & 21.0 & 0.087 & 11.3 \\
\hline $\mathrm{SFT}(\mathrm{mm})$ & 4.12 & 4.64 & 4.63 & 0.331 & 4.34 & 4.58 & 0.458 & 4.38 & 3.54 & 0.008 & 31.9 \\
\hline RHFT (mm) & 3.77 & 4.48 & 4.00 & 0.254 & 3.96 & 4.21 & 0.483 & 5.29 & 2.88 & 0.002 & 37.1 \\
\hline $\mathrm{RCFT}(\mathrm{mm})$ & 4.57 & 4.29 & 4.39 & 0.805 & 4.46 & 4.37 & 0.799 & 5.08 & 3.75 & 0.049 & 32.6 \\
\hline
\end{tabular}

HQ - hindquarter; SFT - subcutaneous fat thickness; RHFT - rump heart fat thickness; RCFT - rump cap fat thickness. 
Although the meat cuts from animals of the different finishing systems were similar, those which presented fat cover, such as sirloin, rump heart and rump cap, had difference $(\mathrm{P}<0.05)$ in the deposition of this fat. The confined animals yielded cuts with greater fat cover (Table 10) such that most of these parts were classified in categories with higher market value, aggregating value to the product.

\section{Conclusions}

The additional gain with the use of protein-energy supplement in the post-weaning phase of Nellore heifers is maintained during the finishing phase both in feedlot and on pasture. Thus, the time necessary to fatten these animals is reduced, in relation to the use of mineral salt. The number of animals slaughtered per area is larger in systems that adopt lower pastures in the post-waning phase, but the time to finish them is longer. Management strategies in the postweaning phase of Nellore heifers do not interfere with their carcass characteristics, regardless of the fattening system. The use of confinement reduces the slaughter age and provides carcasses with greater fat cover, which results in meat cuts of higher commercial value.

\section{References}

ASSOCIATION OF OFFICIALANALYTICAL CHEMISTS - AOAC. Official methods of analysis of the Association of Analytical Chemists. 15.ed. Arlington: 1990.

BAIL, C.A.T.; BRONDANI, I.L.; RESTLE, J. Níveis de concentrado na fase de terminação em confinamento para novilhos previamente mantidos em pastagem nativa ou cultivada. Ciência Rural, v.30, n.1, p.151-157, 2000.

BÜRGER, P.J.; PEREIRA, J.C.; DA SILVA, J.F.C. et al. Taxas de passagem e cinética de degradação ruminal em bezerros holandeses alimentados com dieta contendo diferentes níveis de concentrado, Revista Brasileira de Zootecnia, v.29, n.1, p.225-235, 2000.

CASAGRANDE, D.R. Suplementação de novilhas de corte em pastagem de capim-marandu submetidos a intensidade de pastejo sob lotação contínua. 2010. 127f. Tese (Doutorado em Zootecnia) - Faculdade de Ciências Agrárias e Veterinária, Jaboticabal.

CASAGRANDE, D.C.; RUGGIERI, A.C.; MORETTI, M.H. et al. Sward canopy structure and performance of beef heifers under supplementation in Brachiaria brizantha cv. Marandu pastures maintained with three grazing intensities in a continuous stocking system. Revista Brasileira de Zootecnia, v.40, n.10, p.2078-2082, 2011a.

CASAGRANDE, D.C.; AZENHA, M.V.; VALENTEI, A.L.S. et al. Canopy characteristics and behavior of Nellore heifers in Brachiaria brizantha pastures under different grazing heights at a continuous stocking rate. Revista Brasileira de Zootecnia, v.40, n.11, p.2294-2301, 2011b

CASALI, A.O.; DETMANN, E.; VALADARES FILHO, S.C. et al. Estimação de teores de componentes fibrosos em alimentos para ruminantes em sacos de diferentes tecidos. Revista Brasileira de Zootecnia, v.38, n.1, p.130-138, 2009.

CASALI, A.O.; DETMANN, E.; VALADARES FILHO, S.C. et al. Influência do tempo de incubação e do tamanho de partículas sobre os teores de compostos indigestíveis em alimentos e fezes bovinas obtidos por procedimentos in situ. Revista Brasileira de Zootecnia, v.37, n.2, p.335-342, 2008.

COSTA, P.B.; QUEIROZ, A.C.; RODRIGUES, M.T. et al. Desempenho de novilhas leiteiras sob manejo para crescimento compensatório recebendo suplemento com ionóforo. Revista Brasileira de Zootecnia, v.36, n.2, p.461-470, 2007.

COUTINHO FILHO, J.L.V.; PERES, R.M.; JUSTO, C.L. Produção de carne de bovinos contemporâneos, machos e fêmeas, terminados em confinamento. Revista Brasileira de Zootecnia, v.35, n.5, p.2043-2049, 2006.

DETMANN, E.; PAULINO, M.F.; ZERVOUDAKIS, J.T. et al. Cromo e indicador interno na determinação do consumo de novilhos mestiços, suplementados, a pasto. Revista Brasileira de Zootecnia, v.30, n.5, p.1600-1609, 2001.

FELÍCIO, P.E. Fatores ante e post mortem que influenciam na qualidade da carne bovina. In: PEIXOTO, A.M.; MOURA, J.C.; FARIA, V.P. (Org.). Produção de novilho de corte. 1.ed. Piracicaba: FEALQ, 1997. p.79-97.

GOES, R.H.T.B.; MANCIO, A.B.; LANA, R.P. et al. Avaliação qualitativa da pastagem de capim tanner-grass (Brachiaria arrecta), por três diferentes métodos de amostragem. Revista Brasileira de Zootecnia, v.32, n.1, p.64-69, 2003.

MORETTI, M.H.; REIS, R.A.; CASAGRANDE, D.C. et al. Suplementação protéica energética no desempenho de novilhas em pastejo durante a fase de terminação. Ciência e Agrotecnologia, v.35, n.3, p.606 -612, 2011

PETHICK, D.W.; HARPER, G.S.; ODDY, V.H. Growth, development and nutritional manipulation of marbling in cattle: A review. Australian Journal of Experimental Agriculture, v.44, p.705-715, 2004.

RESENDE, F.D.; SAMPAIO, R.L.; SIQUEIRA, G.R. et al. Estratégias de suplementação na recria e terminação de bovinos de corte. Efeitos do nível de suplementação na recria sobre o desempenho na terminação. In: REUNIÃO ANUAL DA SOCIEDADE BRASILEIRA DE ZOOTECNIA, 45., 2008, Anais... Lavras: UFLA, 2008. (CD-ROM).

RIBEIRO, F.G.; LEME, P.R.; BULLE, M.L.M. et al. Características da carcaça e qualidade da carne de tourinhos alimentados com dietas de alta energia. Revista Brasileira de Zootecnia, v.31, n.2, p.749-756, 2002.

ROBERTSON, J.B.; VAN SOEST, P.J. The detergente system of analysis and its application to human foods. In: JAMES, W.P.T.; THEANDER, O. (Eds.) The analysis of dietary fiber in food. New York: Marcel Dekker, 1985. p.123-158.

ROÇA, R.O. Modificações pós-morte da carne. 2001. Available at: $<$ http://www.fca.unesp.br $>$. Accessed on: Nov. 10, 2011.

RODRÍGUEZ, N.M.; SALIBA, E.O.S.; GUIMARÃES JUNIOR, R. Uso de indicadores para estimativa de consumo a pasto e digestibilidade. In: REUNIÃO ANUAL DA SOCIEDADE BRASILEIRA DE ZOOTECNIA, 43., 2006, João Pessoa. Anais... João Pessoa, 2006. (CD-ROM)

SANTOS, H.G.; JACOMINE, P.K.T.; ANJOS, L.H.C. et al. (Eds.). Sistema brasileiro de classificação de solos. 2.ed. Rio de Janeiro: Embrapa Solos, 2006. 306p.

SILVA, D.J.; QUEIROZ, A.C. Análise de alimentos: métodos químicos e biológicos. 3.ed. Viçosa, MG: UFV, 2002. 335p.

SIQUEIRA, G.R. Aditivos na silagem de cana-de-açúcar in natura ou queimada. 2009. 107f. Tese (Doutorado em Zootecnia) Faculdade de Ciências Agrárias e Veterinária, Jaboticabal.

THIAGO, L.R.L.S.; SILVA, J.M. Suplementação de bovinos em pastejo. Campo Grande: Embrapa Gado de Corte, 2001. 28p. (Documentos 108). 